\title{
Experimental Organism Decidual Reaction
}

National Cancer Institute

\section{Source}

National Cancer Institute. Experimental Organism Decidual Reaction. NCI Thesaurus.

Code C123636.

A primarily uterine reaction with generally indistinct borders and two recognizable regions. These regions are an antimesometrial region containing closely packed mesenchymal cells and a mesometrial region containing mesometrial cells with long cytoplasmic processes and abundant glycogen. (INHAND) 